\title{
Sudanese Dicots as Alternative Fiber Sources for Pulp and Papermaking
}

\section{Sudanske dvosupnice kao alternativni izvor vlakana za proizvodnju celuloze i papira}

\author{
Original scientific paper • Izvorni znanstveni rad \\ Received-prispjelo: 30.8 .2017$. \\ Accepted-prihvaćeno: 23. 5. 2018. \\ UDK: $630 * 861.067 .9$ \\ doi:10.5552/drind.2018.1748
}

\begin{abstract}
The suitability of the stems from two Sudanese dicotyledonous annual plants, namely castor bean (Ricinus communis) and Leptadenia pyrotechnica (L. pyrotechnica) were investigated for pulp and papermaking. Chemical compositions, elemental analysis, fiber dimensions, paper physical properties and morphology revealed a relatively high $\alpha$-cellulose content (46.2 and $44.3 \%$ ) and low lignin (19.7 and $21.7 \%$ ) in the stems of castor bean and L. pyrotechnica, respectively. The average fiber length of castor bean and L. pyrotechnica is 0.80 and $0.70 \mathrm{~mm}$ with fiber width of $16.30 \mu \mathrm{m}$ and $18.20 \mu \mathrm{m}$, respectively, which makes them acceptable candidates. SodaAQ pulping of castor bean stem led to a higher pulp yield of $43.2 \%$ at kappa number 18.2 compared to $40.3 \%$ at kappa 20.3 for L. pyrotechnica. This yield is less than that obtained for wood plants and similar to that observed for annual plants. Paper handsheets produced from castor bean showed better mechanical properties than L. pyrotechnica. SEM images indicated that the produced papers were quite homogeneous, compact, closely packed, and well assembled.
\end{abstract}

Key words: Sudanese annual plants, castor bean, Leptadenia pyrotechnica, pulp and paper

SAŽETAK • U radu je opisano istraživanje prikladnosti stabljika dviju sudanskih jednogodišnjih biljaka dvosupnica, ricinusa (Ricinus communis) i Leptadenia pirotechnica za dobivanje celulozu i proizvodnju papira. Kemijski sastav, elementarna analiza, dimenzije vlakana, fizikalna svojstva papira i morfologija pokazali su da je u stabljikama ricinusa $i$ L. pyrotechnica relativno visok sadržaj $\alpha$-celuloze (46,2 i 44,3\%) i nizak sadržaj lignina (19,7 i 21,7 \%). Prosječna duljina vlakana ricinusa i L. pirotechnice iznosi 0,80 i 0,70 mm, a širina vlakana im je od 16,30 $\mu \mathrm{m}$ i 18,20 $\mathrm{mm}$, što ih čini prihvatljivima za proizvodnju celuloze i papira. Sulfatnim je postupkom od stabljika ricinusa dobiven veći prinos celuloze (43,2\%) pri kappa broju 18,2 u usporedbi s prinosom celuloze (40,3\%) pri kappa broju 20,3, koji je dobiven pri proizvodnji celuloze od stabljika L. pyrotechnice. Dobiveni prinos manji je od prinosa koji se postiže proizvodnjom celuloze od drvenastih biljaka i jednak je prinosu koji se ostvaruje proizvodnjom celuloze od jednogodišnjih biljaka. Listovi papira proizvedeni od ricinusa pokazali su bolja mehanička svojstva od papira proizvedenoga od stabljika L. pyrotechnice. Slike dobivene skenirajućim elektronskim mikroskopom (SEM) pokazuju da su proizvedeni papiri bili posve homogeni, kompaktni, zbijeni i dobro sastavljeni.

Ključne riječi: sudanske jednogodišnje biljke, ricinus, Leptadenia pirotechnica, celuloza i papir

\footnotetext{
${ }^{1}$ Authors are scientists at Key Lab of Pulp and Paper Science and Technology of Ministry of Education (Shandong Province) Qilu University of Technology, Jinan, 250353, Shandong, P.R. China. ${ }^{2}$ Author is assistant professor at Center of Fibers, Papers and Recycling, Faculty of Textiles, University of Gezira, Box 20, Wad Medani, Sudan. ${ }^{3}$ Author is professor at Department of Forest Biomaterials, North Carolina State University, Raleigh, USA.

Autori su znanstvenici Ključnog laboratorija za znanost i tehnologiju celuloze i papira Ministarstva obrazovanja (provincija Shandong), Tehničko sveučilište Qilu, Jinan, Shandong, Kina. ${ }^{2}$ Autor je profesor Centra za vlakna, papir i recikliranje, Tekstilni fakultet Sveučilišta u Geziru, Wad Medani, Sudan. ${ }^{3}$ Autor je profesor Odsjeka za šumske biomaterijale, Državno sveučilište North Carolina, Raleigh, SAD.
} 


\section{INTRODUCTION 1. UVOD}

The annual world consumption of paper and paperboard is growing $2.1 \%$ and it will reach an estimated 490 million tonnes by 2020 (Dutt et al., 2008). However, $\sim 4$ billion trees are cut across the globe for pulp and paper manufacturing often raising ecological and climatic issues (Kamoga et al., 2016) and leading to a demand for alternative pulp and papermaking raw materials. In some countries, pulp and paper industries have been facing some challenges due to the shortages of forest resources (Ferhi et al., 2014b). However, non-wood species or annual plants and agriculture residues are likely the best candidates as alternative sources of cellulosic fibers (Kamoga et al., 2016). Furthermore, as these cellulosic fiber materials have identical properties, they could be used as wood fibers for pulp and papermaking (Mechi et al., 2016), textile, boards, and green composite materials (Mansouri et al., 2012).

Many studies have been carried out to find new alternative lignocellulosic materials. Some of these studies have used tobacco (Shakhes et al., 2011a), rice straw, sugarcane bagasse and cotton stalk (Adel et al., 2016), pineapple (Wutisatwongkul et al., 2016) millet stalks and date palm leaves (Saeed et al., 2017b), J. procera (Nasser et al., 2015), sunflower stalk (Barbash et al., 2016) gracilaria and eucheuma (Machmud et al., 2013), bitter orange (Tutuş et al., 2016), ipomea carnea and cannabis sativa (Dutt et al., 2008), c. orientalis and c. tataria (Tutus et al., 2010), wheat straws (Espinosa et al., 2016) and broad bean, bell pepper and asparagus (Gonzalo et al., 2017). However, there is no previous study on the application of castor bean (Ricinus communis) and Leptadenia pyrotechnica (L. pyrotechnica) stems for pulp and paper production.

Castor bean (Ricinus communis) is a tropical annual and fast-growing plant. It belongs to the Euphorbiaceae family that is grown across the world (de Assis Junior et al., 2011; Udoh and Abu, 2016). Vasconcelos et al. (2014) investigated the physical and chemical properties of fibrous residues of castor bean, and they found that castor bean stems consist of $50.46 \%$ of cellulose, $29.64 \%$ of hemicelluloses, $17.34 \%$ of lignin and $1.48 \%$ of ash.

Leptadenia pyrotechnica (L. pyrotechnica) is an important multipurpose non-wood species of tropical and sub-tropical arid regions. Mojumder et al. (2001) investigated the chemical composition of L. pyrotechnica, and determined that it consists of $4.93 \%$ of lignin, $75.26 \%$ of $\alpha$-cellulose and $2.77 \%$ of ash. However, the results reveal that castor and L. pyrotechnica residues are a good alternative for the pulp and paper industries since they are plants of high cellulose content. This work investigated the chemical components and fiber properties of castor bean (Ricinus communis) and L. pyrotechnica stems after sodaAQ pulping.

\section{MATERIALS AND METHODS 2. MATERIJALI I METODE \\ 2.1 Materials \\ 2.1. Materijali}

Castor bean (Ricinus communis) and L. pyrotechnica stems were collected from North Kordofan State, west of Sudan (latitudes $12^{\circ} 30$ North and longitudes $29^{\circ} 30$ East) in March 2017. Materials were randomly selected according to TAPPI standard methods. A part of the material was chipped to $1.5 \times 1.5 \times 2 \mathrm{~cm}$ and ground to powder with a mesh size of 40-60 in a laboratory by using a Wiley mill grinder for determining their chemical components. Hydrogen peroxide $\left(\mathrm{H}_{2} \mathrm{O}_{2}\right)$, sodium hydroxide $(\mathrm{NaOH})$, sodium oxide $\left(\mathrm{Na}_{2} \mathrm{O}\right)$, acetic acid and anthraquinone (AQ) were acquired from Sinopharm Chemical Reagent Co., Ltd. (Shanghai, China).

\subsection{Methods \\ 2.2. Metode}

\subsubsection{Chemical composition}

2.2.1. Kemijski sastav

Materials were tested for extractive substances in different liquids according to common TAPPI standards: cold and hot water T207 cm-99, 1 \% sodium hydroxide solution T212 om-98 and alcohol-toluene T204 cm-97 (López et al., 2011). The amounts of lignin and ash contents were assessed according to T222 cm-99 and T211 om-02 (Yuan et al., 2016), while, holocellulose contents were determined according to Wise method (Wise, 1946).

\subsubsection{Morphological characteristics 2.2.2. Morfološka obilježja}

For the measurements of fiber dimensions, samples were macerated in a mixture of $30 \%$ hydrogen peroxide and acetic acid (1:1). Fiber length, width and kinked and curled index were measured with FQA device (OpTest, Canada), model LDA-02 according to T271 om-07. Lumen diameter and wall thickness were measured by Leica DMLB (Leica Microsystems $\mathrm{GmbH}$, Wetzlar, Germany) connected to a video camera Leica DFC490 (Leica Microsystems GmbH, Wetzlar, Germany) at $400 \times$ magnifications. Fibers morphology and elemental composition (Carbon (C), Oxygen (O), Aluminium (Al), Nitrogen $(\mathrm{N})$, silicon $(\mathrm{Si})$, magnesium $(\mathrm{Mg})$, and Calcium $(\mathrm{Ca})$ ) were determined using a scanning electron microscope (SEMEDS) by (OCTANE 9.88/1114658 AMETEK $^{\circledR}$ (USA)). Before the test, the paper specimens were coated with gold-palladium in a Sputtergerät SCD 005 sputter coater (England). A sputter current of $60 \mathrm{~mA}$, sputter time $90 \mathrm{~s}$, and film thickness of $20 \mathrm{~nm}$ to $25 \mathrm{~nm}$ were chosen as the coating conditions.

\subsubsection{Pulping processing and testing}

2.2.3. Proizvodnja i ispitivanje celuloze

Soda-AQ pulping was carried out in a rotary digester with electrical heating with four individual $2 \mathrm{~L}$ vessels. The charge was $100 \mathrm{~g}$ of oven dried (o.d.) material. The active alkali $(\mathrm{NaOH})$ was constant $20 \%$ on oven dried (o.d.), while AQ was $0.1 \%$. The cooking 
was continued for $120 \mathrm{~min}$ at the maximum temperature of $170{ }^{\circ} \mathrm{C}$. At the end of pulping, pressure was relieved to atmospheric pressure; pulp was taken out from the digester, disintegrated and washed by continuous water flow. Pulp was screened on a $0.15 \mathrm{~mm}$ laboratory slot vibratory screener and the yield was determined gravimetrically. Pulp yield was determined as dry matter obtained on the basis of o.d. raw material. The pulp was subjected to mechanical beating using the PFI mill according to T248 sp-00, kappa number was determined according to T $236 \mathrm{~cm}-85$ (Sarker et al., 2017), while pulp viscosity was determined according to T 230 om-04 (Feria et al., 2012). Moreover, a totally chlorine-free bleaching was carried out. According to Moral et al. (2016) $10 \%$ pulp concentration is bleached in two stages by $4 \%$ hydrogen peroxide $\left(\mathrm{H}_{2} \mathrm{O}_{2}\right)$ in $0.2 \%$ sodium hydroxide $(\mathrm{NaOH})$ at $80^{\circ} \mathrm{C}$ for $2 \mathrm{~h}$ of each stage. The pulp was washed properly until neutralization in every stage.

\subsubsection{Papermaking and testing}

2.2.4. Proizvodnja i ispitivanje papira

All pulps were beaten to 5000 revolution at $35^{\circ} \mathrm{SR}$ in a PFI mill T248 sp-00, and papers of 60 grams were made according to the T205sp -95 in a laboratory handsheet machine (PTI laboratory Equipment, Vorchdorf, Austria). The physical properties of the samples were determined according to common standards: burst index T403 om-10, tear index T414 om- 04 and tensile index T494 om-06 (Rudi et al., 2016). The brightness and opacity were determined according to T525 om-92 and T425 om-96 (Tutuş et al., 2016), respectively.

\subsubsection{Calculations}

\subsubsection{Proračuni}

The following parameters were calculated using the following formulas (Albert et al., 2011; Pirralho et al., 2014).

Slenderness ratio $=$ fiber length $\div$ fiber diameter

Flexibility coefficient $=($ fiber lumen diameter $\div$ (iber diameter $) \times 100$
Runkel ratio $=(2 \times$ fiber cell wall thickness $)$

$\div$ lumen diameter

Rigidity coefficient $=($ cell wall thickness $\times 100)$

$\div$ fiber diameter

Felting power $=$ fiber length $\div$ fiber width

\section{RESULTS AND DISCUSSION 3. REZULTATI I RASPRAVA}

Chemical composition and extractives of castor bean and L. pyrotechnica in comparison with some common representatives of lignocellulosic annual plants are shown in Table 1. Castor bean and L. pyrotechnica show a relatively high cellulose content of $46.20 \%$ and 44.30 $\%$, respectively, compared to prunus amygdalus (Mechi et al., 2017), A. armatus (Ferhi et al., 2014a) vine stems (Mansouri et al., 2012) and bagasse (Saeed et al., 2017a), but lower than that of I. tinctoria (Comlekcioglu et al., 2016), cactus (Mannai et al., 2017) and similar to that of palm leaves (Saeed et al., 2017b). On the other hand, L. pyrotechnica show a higher amount of hemicellulose $(22.15 \%)$ compared to castor bean value of 20.50 $\%$. This result may explain the higher solubility of $L$. pyrotechnica in alkali solution $(1 \% \mathrm{NaOH})$, because it is adequate to dissolve the fragile branched components of the cellulosic chain, such as hemicelluloses (Mattos et al., 2016). However, these results are not in line with vine stems (Mansouri et al., 2012) and A. armatus (Ferhi et al., 2014a). Lignin content was found to be higher in L. pyrotechnica $(21.70 \%$ ), while it was $19.70 \%$ in castor bean. However, these results are comparable with those of the listed annual plants and hardwoods (17-26 $\%$ ) and lower than those of softwoods (25-32\%) (Ates et al., 2008). Castor bean and L. pyrotechnica showed almost the same ash contents, 2.60 and $2.40 \%$, respectively, which is the range (1-3\%) for hardwoods and less than those of the materials listed in Table 1. However, high ash content is undesirable, as trace elements interfere with bleaching chemicals and alkali earth metals in the pulp will cause problems in chemical recovery. Moreover, high ash content may lead to damage in wood during processing (Dutt et al., 2009, López et al., 2012).

Table 1 Chemical composition of castor bean, L. pyrotechnica and some other annual plants

Tablica 1. Kemijski sastav ricinusa, L. pyrotechnica i nekoliko drugih jednogodišnjih biljaka

\begin{tabular}{|c|c|c|c|c|c|c|c|c|c|}
\hline \multirow[b]{2}{*}{$\begin{array}{c}\text { Annual plants } \\
\text { Jednogodišnje biljke }\end{array}$} & \multicolumn{4}{|c|}{$\begin{array}{c}\text { Chemical compositions } \\
\text { Kemijski sastav }\end{array}$} & \multicolumn{4}{|c|}{ Solubility / Topljivost } & \multirow[b]{2}{*}{$\begin{array}{l}\text { Literature } \\
\text { Literatura }\end{array}$} \\
\hline & 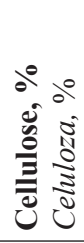 & 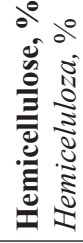 & 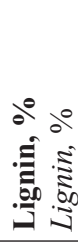 & $\mid \begin{array}{cc}0 & 0 \\
0 & 8 \\
\bar{z} & 8 \\
\frac{0}{4} & 0 \\
2\end{array}$ & 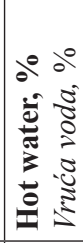 & 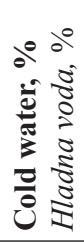 & 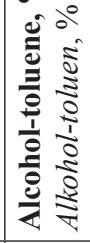 & 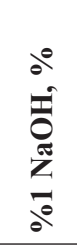 & \\
\hline Castor bean / ricinus & 46.2 & 20.5 & 19.7 & 2.6 & 10.5 & 9.4 & 4.8 & 18.6 & Current Study \\
\hline L. pyrotechnica & 44.3 & 22.1 & 21.7 & 2.4 & 12.1 & 11.5 & 5.6 & 20.9 & Current Study \\
\hline Prunus amygdalus & 40.7 & 20.0 & 19.2 & 3.6 & 12.3 & 11.3 & 5.0 & 28.7 & Mechi et al. (2016), \\
\hline I. tinctoria & 48.5 & 18.6 & 23.9 & 4.9 & 17.2 & 13.6 & 4.4 & 43.8 & Comlekcioglu et al. (2016) \\
\hline A. armatus & 41.5 & 29.3 & 19.0 & 2.8 & 15.6 & 12.2 & 4.0 & 39.0 & Ferhi et al. (2014) \\
\hline Vine stems / stabljike vinove loze & 35.0 & 30.4 & 28.1 & 3.9 & 13.9 & 8.2 & 11.3 & 37.8 & Mansouri et al. (2012) \\
\hline
\end{tabular}


The extractives also contain extraneous ingredients, such as inorganic compounds, tannins, gums, sugars and coloring in the lignocellulosic plants (Dutt et al., 2009). The amount of extractives of castor bean and L. pyrotechnica in hot and cold water is relatively high compared to hardwood (2-8 \%) (Ferhi et al., 2014b), but less than that of several annual plants such as I. Tinctoria (Comlekcioglu et al., 2016) and A. armatus (Mechi et al., 2016). However, it is comparable to other annual plants such as Prunus amygdalus (Mechi et al., 2016). The extractives in $1 \% \mathrm{NaOH}$ are $18.60 \%$ and $20.90 \%$ for castor bean and L. pyrotechnica, respectively, lower than those for annual plants listed in Table 1. Castor bean showed similar alcohol-toluene extractives to $I$. tinctoria (Comlekcioglu et al., 2016) and A. armatus (Ferhi et al., 2014a). Among the listed data, castor bean showed the least hot and cold water and $1 \% \mathrm{NaOH}$ extractives. However, the lower solubility resulted in high pulp yield and less chemical consumption in pulping and bleaching processing (Comlekcioglu et al., 2016). The large cellulose contents and lower lignin content enhance the investigation of such annual plants as they have a high potential for use as fibers for pulp and paper production.

The basic parameters that affected the physical properties of the paper are fiber dimensions including fiber length, fiber width and fiber cell wall thickness (Albert et al., 2011). The average fiber length of castor bean and L. pyrotechnica are 0.80 and $0.70 \mathrm{~mm}$, respectively. They are less than that of softwood (2.7-4.6 mm) and in the range of hardwood $(0.7-1.6 \mathrm{~mm})$ (Comlekcioglu et $a l ., 2016)$ and they are considered as short fiber species (Jahan et al., 2008). These fibers were similar to A. armatus (Ferhi et al., 2014a) and longer than vine stems (Mansouri et al., 2012) and prunus amygdalus (Mechi et al., 2017). It is expected that paper handsheets produced from L. pyrotechnica pulp with relatively short fibers may give a smoother paper than that of castor bean because short fibers will fill the voids in the paper sheet, while the paper handsheet formed from castor bean pulps would result in higher strength properties and less fine sheet structure (Nasser et al., 2015). Moreover, the higher the fiber length, the better will be the tearing resistance of paper (Agnihotri et al., 2010). Therefore, paper made from these materials showed good mechanical strength and can be suitable for producing writing and printing papers as well as wrapping and packaging paperboard. On the other hand, L. pyrotechnica showed a thicker fiber with the width of $18.20 \mu \mathrm{m}$ compared to the $16.30 \mu \mathrm{m}$ of castor bean. However, the observed fibers are thinner than those of $A$. armatus (Ferhi et al., 2014a), and those of Prunus amygdalus (Mechi et al., 2017) are thicker than those of I. tinctoria (Comlekcioglu et al., 2016). Cell wall thickness of castor bean $(6.40 \mu \mathrm{m})$ is lower compared to that of L. pyrotechnica $(7.00 \mu \mathrm{m})$ and I. tinctoria (Comlekcioglu et al., 2016), However, longer fiber with lower cell wall thickness showed significant advantages in physical properties of the produced paper (Tutus et al., 2010).

Values derived from the fiber dimensions, important for determining the suitability of the material for paper production, are listed in Table 2. Castor bean showed a relatively high felting power of 49 compared to 38.46 for L. pyrotechnica. However, these values are similar to those of hardwood (40-55) and lower than those of softwood (60-80) (Comlekcioglu et al., 2016). If the felting power of a fibrous material is lower than 70 , it is suitable for the pulp and paper industry (Tutus et al., 2010). The values of the rigidity coefficient negatively influence tensile, tear, burst and double fold resistance of the paper (Anoop et al., 2014). Both castor bean and L. pyrotechnica fibers showed higher rigidity coefficients of 38.04 and 38.46, respectively, compared to 30.44 of cymodocea serrulata (Syed et al., 2016) and 26.40 of I. tinctoria (Comlekcioglu et al., 2016). Moreover, it was reported that, if the slenderness ratio of fibrous material is less than 70 and higher than 33 , the lignocellulosic material is considered to be good for pulp and paper production (Shakhes et al., 2011a; Syed et al., 2016). Both castor bean and L. pyrotechnica showed slenderness ratios of 49.00 and 38.46, respectively. Castor bean had a relatively high flexibility coefficient of 63.19 compared to 62.64 and 47.2 of $L$. pyrotechnica and I. tinctoria, respectively. Previous

Table 2 Fiber properties of castor bean, L. pyrotechnica and some annual plants

Tablica 2. Obilježja vlakanaca ricinusa, L. pyrotechnica i nekoliko drugih jednogodišnjih biljaka

\begin{tabular}{|l|c|c|c|c|c|c|}
\hline \multicolumn{1}{|c|}{$\begin{array}{c}\text { Material } \\
\text { Materijal }\end{array}$} & $\begin{array}{c}\text { Castor } \\
\text { Bean } \\
\text { Ricinus }\end{array}$ & L. pyrotechnica & $\begin{array}{c}\text { Prunus } \\
\text { amygdalus }\end{array}$ & I. tinctoria & A. armatus & $\begin{array}{c}\text { Vine stems } \\
\text { Stabljike } \\
\text { vinove loze }\end{array}$ \\
\hline Fiber length, mm / Duljina vlakana, $\mathrm{mm}$ & $0.80 \pm 0.05$ & $0.70 \pm 0.06$ & 0.48 & 0.60 & 0.81 & 0.59 \\
\hline Fiber width, $\mu \mathrm{m} /$ Širina vlakana, $\mu \mathrm{m}$ & $16.30 \pm 1.4$ & $18.20 \pm 2.2$ & 21.00 & 15.70 & 20.60 & 24.60 \\
\hline Lumen diameter, $\mu \mathrm{m} /$ Promjer lumena, $\mu \mathrm{m}$ & $10.30 \pm 1.5$ & $11.40 \pm 1.3$ & N/A & 8.80 & N/A & N/A \\
\hline $\begin{array}{l}\text { Cell wall thickness, } \mu \mathrm{m} \\
\text { Debljina stanične stijenke, } \mu \mathrm{m}\end{array}$ & $6.20 \pm 1.1$ & $7.00 \pm 2.1$ & N/A & 8.60 & N/A & N/A \\
\hline Felting power / Snaga filcanja & 49.00 & 38.46 & N/A & 39.7 & N/A & N/A \\
\hline Rigidity coefficient / Koeficijent krutosti & 38.04 & 38.46 & N/A & 26.4 & N/A & N/A \\
\hline Slenderness ratio / Vitkost & 49.00 & 38.46 & N/A & N/A & N/A & N/A \\
\hline Flexibility coefficient / Omjer fleksibilnosti & 63.19 & 62.64 & N/A & 47.2 & N/A & N/A \\
\hline Runkel ratio / Runkelov omjer & 1.20 & 1.23 & N/A & 1.1 & N/A & N/A \\
\hline Literature / Literatura & $\begin{array}{c}\text { Current } \\
\text { Study }\end{array}$ & Current Study & 1 & 2 & 3 & 4 \\
\hline
\end{tabular}

${ }^{1)}$ Mechi et al. (2016), ${ }^{2)}$ Comlekcioglu et al. (2016), ${ }^{3)}$ Ferhi et al. (2014), ${ }^{4)}$ Mansouri et al. (2012), N/A: Not available 
Table 3 Properties of pulp from castor bean, L. pyrotechnica and some annual plants

Tablica 3. Svojstva celuloze proizvedene od ricinusa, L. pyrotechnica i nekoliko drugih jednogodišnjih biljaka

\begin{tabular}{|l|c|c|c|c|c|}
\hline \multicolumn{1}{|c|}{$\begin{array}{c}\text { Material } \\
\text { Materijal }\end{array}$} & $\begin{array}{c}\text { Total yield } \\
\text { Ukupni prinos } \\
\%\end{array}$ & $\begin{array}{c}\text { Screened yield } \\
\text { Prinos prosijavanja } \\
\%\end{array}$ & $\begin{array}{c}\text { Kappa } \\
\text { number } \\
\text { Kapa broj }\end{array}$ & $\begin{array}{c}\text { Viscosity } \\
\text { Viskoznost } \\
\mathrm{mPa} \cdot \mathrm{s}\end{array}$ & $\begin{array}{c}\text { Literature } \\
\text { Literatura }\end{array}$ \\
\hline Castor bean / ricinus & 43.20 & 42.10 & 18.20 & 6.46 & Current study \\
\hline L. pyrotechnica & 40.30 & 38.80 & 20.30 & 5.12 & Current study \\
\hline Prunus amygdalus & 45.2 & 42.94 & N/A & 5.28 & 1 \\
\hline I. tinctoria & 26.09 & 25.37 & N/A & N/A & 2 \\
\hline A. armatus & 32.00 & N/A & 15.20 & N/A & 3 \\
\hline Vine stems / stabljike vinove loze & 45.00 & N/A & 25.50 & 8.50 & 4 \\
\hline
\end{tabular}

${ }^{1)}$ Mechi et al. (2016), ${ }^{2)}$ Comlekcioglu et al. (2016), ${ }^{3)}$ Ferhi et al. (2014), ${ }^{4)}$ Mansouri et al. (2012), N/A: Not available

studies stated that higher Runkel ratio fibers are stiffer, less flexible, and form bulkier paper of lower fiber to fiber bond than lower Runkel ratio fibers. High average fiber length and low Runkel ratio result in good pulp strength properties (Shakhes et al., 2011b). Both castor bean and L. pyrotechnica showed high Runkel ratio of 1.20 and 1.23 compared to that of 1.1 of I. tinctoria.

The physical properties of the pulp obtained from the studied materials are summarized in Table 3. The results reveal that castor bean shows higher total pulp yield of $43.20 \%$ with an acceptable kappa number of 18.20 compared to that of $40.30 \%$ with kappa number of 20.30 of $L$. pyrotechnica. The low pulp yield of $L$. pyrotechnica is attributed to a relatively high content of extractives, especially in hot and cold water compared to that of castor bean (Ferhi et al., 2014a) as well as low cellulose content (Gonzalo et al., 2017). These values are higher than those of $A$. armatus (Ferhi et al., 2014a) and I. tinctoria (Comlekcioglu et al., 2016) and lower than those of vine stems (Mansouri et al., 2012) and $A$. armatus (Ferhi et al., 2014a). However, the differences in kappa number could be attributed to differences in lignin content in the materials. The value of viscosity is an indicator of fiber length and degree of polymerization (Kamoga et al., 2016). However, caster bean showed higher viscosity $(6.46 \mathrm{mP} \cdot \mathrm{s})$ compared to that of $L$. pyrotechnica $(5.12 \mathrm{mP} \cdot \mathrm{s})$ and prunus amygdalus $(5.28$ $\mathrm{mP} \cdot \mathrm{s}$ ) (Mechi et al., 2017) but lower than that of vine stems (8.50 $\mathrm{m} \mathrm{mP} \cdot \mathrm{s})$ (Mansouri et al., 2012).

\subsection{Handsheet physical properties}

3.1. Fizikalna svojstva listova papira

The physical and optical properties of handmade paper sheets produced from soda-AQ pulps of the studied annual plants are listed in Table 4. The paper handsheets produced from these species had good formation with basis weights of 63 and $65 \mathrm{~g} / \mathrm{m}^{2}$ and thicknesses of 115 and $117 \mu \mathrm{m}$ for castor bean and L. pyrotechnica, respectively. Hand sheet formed from castor bean showed higher values of tensile, tear and burst index compared to those of paper produced from L. pyrotechnica and Prunus amygdalus (Mechi et al., 2016). Castor bean and L. pyrotechnica papers showed a lower tearing index than that of $A$. armatus (Ferhi et al., 2014a) and vine stems (Mansouri et al., 2012). Remarkably high brightness of 75.20 and $69.20 \%$ was achieved for caster bean and L. pyrotechnica with a preliminary bleaching sequence. This high brightness predicts good bleachability of the pulps from these two annual plants, meaning that lower chemical charges are required.

\subsection{Morphological analysis of papers obtained from castor bean and $L$. pyrotechnica \\ 3.2. Morfološka analiza papira proizvedenoga od stabljika ricinusa i $L$. pyrotechnica}

Paper handsheets were observed by SEM and SEM-EDS analysis, as presented in Fig. 1. Handsheets were magnified at $500 \mathrm{x}$. SEM images indicated that the produced papers are quite homogeneous, compact,

Table 4 Physical properties of papers from castor bean, L. pyrotechnica and several annual plants

Tablica 4. Fizikalna svojstva papira proizvedenoga od ricinusa, L. pyrotechnica i nekoliko drugih jednogodišnjih biljaka

\begin{tabular}{|l|c|c|c|c|c|c|}
\hline \multicolumn{1}{|c|}{$\begin{array}{c}\text { Properties } \\
\text { Svojstvo }\end{array}$} & $\begin{array}{c}\text { Castor bean } \\
\text { Ricinus }\end{array}$ & L. pyrotechnica & $\begin{array}{c}\text { Prunus } \\
\text { amygdalus }\end{array}$ & I. tinctoria & A. armatus & $\begin{array}{c}\text { Vine stems } \\
\text { Stablike vinove } \\
\text { loze }\end{array}$ \\
\hline Thickness, $\mu \mathrm{m} /$ debljina, $\mu \mathrm{m}$ & $115 \pm 4$ & $117 \pm 5$ & $110 \pm 8$ & $\mathrm{~N} / \mathrm{A}$ & 144 & $\mathrm{~N} / \mathrm{A}$ \\
\hline $\begin{array}{l}\text { Basis weight, } \mathrm{g} / \mathrm{m}^{2} \\
\text { osnovna jedinična masa, g/m² }\end{array}$ & $63 \pm 0.5$ & $65 \pm 0.2$ & $64 \pm 0.8$ & $\mathrm{~N} / \mathrm{A}$ & 65.20 & 69.50 \\
\hline $\begin{array}{l}\text { Tensile index, } \mathrm{N} \cdot \mathrm{m} / \mathrm{g} \\
\text { vlačni indeks, } \mathrm{N} \cdot \mathrm{m} / \mathrm{g}\end{array}$ & $4.5 \pm 0.15$ & $3.10 \pm 0.20$ & $4.08 \pm 0.16$ & 3.33 & 3.37 & N/A \\
\hline $\begin{array}{l}\text { Tearing Index, } \mathrm{mN} \cdot \mathrm{m}^{2} / \mathrm{g} \\
\text { indeks cijepanja, } \mathrm{mN} \cdot \mathrm{m}^{2} / \mathrm{g}\end{array}$ & $2.24 \pm 0.26$ & $2.01 \pm 0.54$ & $2.19 \pm 0.27$ & 1.03 & 3.57 & 5.74 \\
\hline $\begin{array}{l}\text { Bursting Index, } \mathrm{kPa} \cdot \mathrm{m}^{2} / \mathrm{g} \\
\text { Indeks pucanja, } \mathrm{kPa} \cdot \mathrm{m}^{2} / \mathrm{g}\end{array}$ & $1.84 \pm 0.03$ & $1.45 \pm 0.02$ & $1.38 \pm 0.05$ & 2.17 & 1.62 & 1.72 \\
\hline Opacity, \% / neprozirnost, \% & $99.20 \pm 5.2$ & $98.00 \pm 15$ & $99.84 \pm 8.5$ & 99.65 & $\mathrm{~N} / \mathrm{A}$ & \\
\hline Brightness, \% / sjajnost, \% & $75.20 \pm 3.1$ & $69.20 \pm 2.4$ & N/A & 25.22 & N/A & 70.00 \\
\hline Literature / literatura & Current Study & Current Study & 1 & 2 & 3 & 4 \\
\hline
\end{tabular}

${ }^{1)}$ Mechi et al. (2016), ${ }^{2)}$ Comlekcioglu et al. (2016), ${ }^{3)}$ Ferhi et al. (2014), ${ }^{4)}$ Mansouri et al. (2012), N/A: Not available 

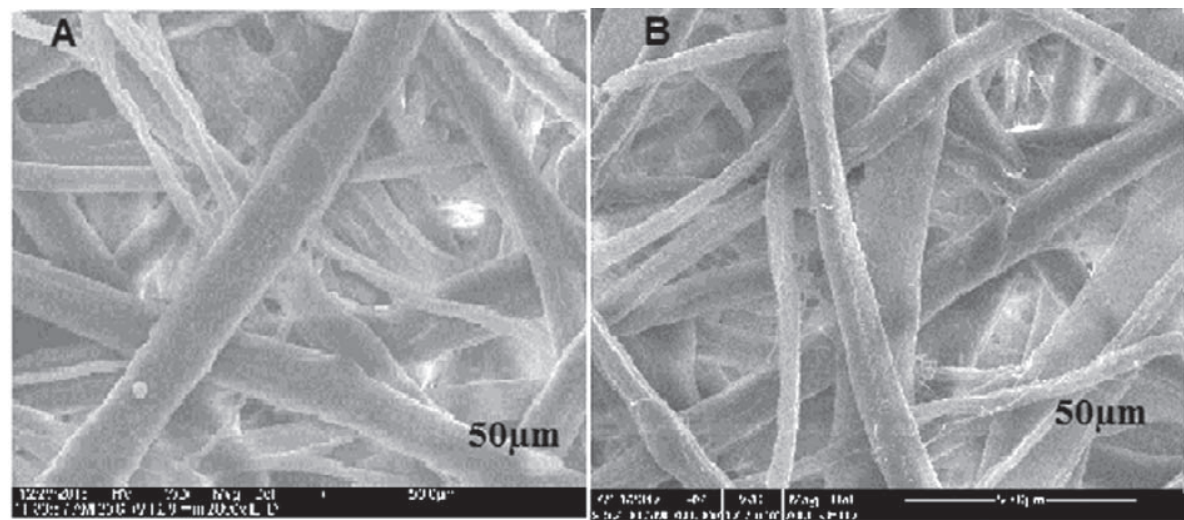

Figure 1 Scanning electron microscopy of (A) L. pyrotechnica, (B) castor bean

Slika 1. Slike dobivene skenirajućim elektronskim mikroskopom (A) L. pyrotechnica, (B) ricinus

Table 5 Elemental analysis of castor bean and L. pyrotechnica

Tablica 5. Elementarna analiza ricinusa i L. pyrotechnica

\begin{tabular}{|l|c|c|c|c|c|c|c|}
\hline Material / Materijal & C (\%) & O (\%) & N (\%) & Mg (\%) & Al (\%) & Si (\%) & Ca (\%) \\
\hline Castor bean / ricinus & 49.49 & 43.17 & 0.90 & 0.02 & 0.12 & 0.07 & 0.13 \\
\hline L. pyrotechnica & 49.93 & 42.24 & 1.19 & 0.05 & 0.04 & 0.10 & 0.08 \\
\hline
\end{tabular}

with a closely packed arrangement and good assembling. Well-arranged and compact fibers will lead to smooth surface and good structure of the produced paper, and thus higher mechanical properties could be obtained (Saeed et al., 2017a).

\subsection{Elemental analysis of castor bean and $L$. pyrotechnica}

3.3. Elementarna analiza ricinusa i L. pyrotechnica

The detailed elemental analysis of castor bean and L. pyrotechnica is listed in Table 5. It clearly shows that ash is mainly composed of $\mathrm{O}, \mathrm{C}, \mathrm{Mg}, \mathrm{N}, \mathrm{Al}, \mathrm{Ca}$ and $\mathrm{Si}$ atoms. Silicon is negligible in both castor bean and L. pyrotechnica $(0.07 \%$ and $0.10 \%)$. Similar results were observed for gracilaria and eucheuma (Machmud et al., 2013). High silicon-containing lignocellulosic materials are generally not preferable for pulping because they contribute to system issues in cooking and washing (Ferhi et al., 2014a).

\section{CONCLUSIONS}

\section{ZAKLJUČAK}

The chemical composition of castor bean and $L$. pyrotechnica stems revealed a sufficient level of polysaccharides and reduced lignin contents compared to other annual plants, which explains their suitability as new lignocellulosic candidates for pulp and paper making. The pulp and paper of castor bean were identified with acceptable yield, medium viscosity, high bleachability, long and narrow fibers compared to $L$. pyrotechnica. Values derived from fiber dimensions, such as felting power, rigidity coefficient and slenderness ratio, determined the suitability of the material for paper production. SEM images indicated that the produced papers are quite homogeneous, compact, with a closely packed arrangement and good assembling, thus providing good mechanical properties of the produced papers.

\section{Acknowledgements - Zahvala}

The authors are grateful for the financial support received from the National Science Foundation of China (Grant Nos. 31470602, 31600472, and 31570566,), the Foundation for Outstanding Young Scientist in Shandong Province (BS2015SW011), the Project of Shandong Province Higher Education Science and Technology Program (No. J13LD03), and the Foundation of Key Laboratory of Pulp and Paper Science and Technology of the Ministry of Education (Shandong Province) of China.

\section{REFERENCES}

\section{LITERATURA}

1. Adel, A. M.; El-Gendy, A. A.; Diab, M. A.; Abou-Zeid, R. E.; El-Zawawy, W. K.; Dufresne, A., 2016: Microfibrillated cellulose from agricultural residues. Part I: Papermaking application. Industrial Crops and Products, 93: 161-174.

https://doi.org/10.1016/j.indcrop.2016.04.043.

2. Agnihotri, S.; Dutt, D.; Tyagi, C., 2010: Complete characterization of bagasse of early species of Saccharum officinerum-Co 89003 for pulp and paper making. BioResources, 5 (2): 1197-1214.

3. Albert, S.; Padhiar, A.; Gandhi, D., 2011: Fiber properties of Sorghum halepense and its suitability for paper production. Journal of Natural Fibers, 8 (4): 263-271. https://doi.org/10.1080/15440478.2011.626236.

4. Anoop, E.; Ajayghosh, V.; Nijil, J.; Jijeesh, C., 2014: Evaluation of pulp wood quality of selected tropical pines raised in the high ranges of Idukki District, Kerala. Journal of Tropical Agriculture, 52 (1): 59-66.

5. Ates, S.; Ni, Y.; Akgul, M.; Tozluoglu, A., 2008: Characterization and evaluation of Paulownia elongota as a raw material for paper production. African journal of biotechnology, 7 (22): 4153-4158.

6. Barbash, V.; Trembus, I.; Alushkin, S.; Yashchenko, O., 2016: Comparative pulping of sunflower stalks. Science Rise, 3 (2 (20)): 71-78.

https://doi.org/10.15587/2313-8416.2016.63098. 
7. Comlekcioglu, N.; Tutus, A.; Cicekler, M.; Canak, A.; Zengin, G., 2016: Investigation of Isatis Tinctoria and Isatis Buschiana Stalks as Raw Materials for Pulp and Paper Production. Drvna industrija, 67 (3): 249-255. https://doi.org/10.5552/drind.2016.1542.

8. de Assis Junior, E. M.; dos Santos Fernandes, I. M.; Santos, C. S.; de Mesquita, L. X.; Pereira, R. A.; Maracajá, P. B.; Soto-Blanco, B., 2011: Toxicity of castor bean (Ricinus communis) pollen to honeybees. Agriculture, ecosystems \& environment, 141 (1): 221-223. https://doi.org/10.1016/j.agee.2011.02.010.

9. Dutt, D.; Upadhyay, J.; Singh, B.; Tyagi, C., 2009: Studies on Hibiscus cannabinus and Hibiscus sabdariffa as an alternative pulp blend for softwood: An optimization of kraft delignification process. Industrial crops and products, 29 (1): 16-26. https://doi.org/10.1016/j.indcrop.2008.03.005

10. Dutt, D.; Upadhyaya, J.; Tyagi, C.; Kumar, A.; Lal, M., 2008: Studies on Ipomea carnea and Cannabis sativa as an alternative pulp blend for softwood: An optimization of kraft delignification process. Industrial Crops and Products, 28 (2): 128-136. https://doi.org/10.1016/j.indcrop.2008.02.001

11. Espinosa, E.; Tarrés, Q.; Delgado-Aguilar, M., González, I.; Mutjé, P.; Rodríguez, A., 2016: Suitability of wheat straw semichemical pulp for the fabrication of lignocellulosic nanofibres and their application to papermaking slurries. Cellulose, 23 (1): 837-852. https://doi.org/10.1007/s10570-015-0807-8

12. Ferhi, F.; Das, S.; Elaloui, E.; Moussaoui, Y.; Yanez, J. G., 2014a: Chemical characterisation and suitability for papermaking applications studied on four species naturally growing in Tunisia. Industrial Crops and Products, 61: $180-185$. https://doi.org/10.1016/j.indcrop.2014.07.001

13. Ferhi, F.; Das, S.; Moussaoui, Y.; Elaloui, E.; Yanez, J. G., 2014b: Paper from Stipagrostis pungens. Industrial Crops and Products, 59: 109-114. https://doi.org/10.1016/j.indcrop.2014.05.015

14. Feria, M.; García, J.; Díaz, M.; Fernández, M.; López, F., 2012: Biorefinery process for production of paper and oligomers from Leucaena leucocephala K360 with or without prior autohydrolysis. Bioresource technology, 126: 64-70. https://doi.org/10.1016/j.biortech.2012.09.051

15. Gonzalo, A.; Bimbela, F.; Sánchez, J.; Labidi, J.; Marín, F.; Arauzo, J., 2017: Evaluation of different agricultural residues as raw materials for pulp and paper production using a semichemical process. Journal of Cleaner Production, 156 (10): 184-193.

https://doi.org/10.1016/j.jclepro.2017.04.036

16. Jahan, M. S.; Sabina, R.; Rubaiyat, A., 2008: Alkaline pulping and bleaching of Acacia auriculiformis grown in Bangladesh. Turkish Journal of Agriculture and Forestry, 32 (4): 339-347.

17. Kamoga, O. L.; Kirabira, J.; Byaruhanga, J.; Godiyal, R.; Anupam, K., 2016: Characterisation and evaluation of pulp and paper from selected Ugandan grasses for paper industry. Cellul. Chem. Technol, 50: 275-284.

18. López, F.; Pérez, A.; García, J.; Feria, M.; García, M.; Fernández, M., 2011: Cellulosic pulp from Leucaena diversifolia by soda-ethanol pulping process. Chemical engineering journal, 166 (1): 22-29. https://doi.org/10.1016/j.cej.2010.08.039

19. López, F.; Pérez, A.; Zamudio, M. A.; De Alva, H. E.; García, J. C., 2012: Paulownia as raw material for solid biofuel and cellulose pulp. Biomass and Bioenergy, 45: 77-86. https://doi.org/10.1016/j.biombioe.2012.05.010

20. Machmud, M. N.; Fadi, F.; Fuadi, Z.; Kokarkin, C., 2013: Alternative Fiber Sources from Gracilaria Sp and Eucheuma Cottonii for Papermaking. International Journal of Science and Engineering, 6 (1): 1-10. https://doi.org/10.12777/ijse.6.1.1-10

21. Mannai, F.; Ammar, M.; Yanez, J. G.; Elaloui, E.; Moussaoui, Y., 2017: Alkaline Delignification of Cactus Fibres for Pulp and Papermaking Applications. Journal of Polymers and the Environment, 1-9.

22. Mansouri, S.; Khiari, R.; Bendouissa, N.; Saadallah, S.; Mhenni, F.; Mauret, E., 2012: Chemical composition and pulp characterization of Tunisian vine stems. Industrial Crops and Products, 36 (1): 22-27.

https://doi.org/10.1016/j.indcrop.2011.07.036

23. Mattos, B. D.; Lourençon, T. V.; Gatto, D. A.; Serrano, L.; Labidi, J., 2016: Chemical characterization of wood and extractives of fast-growing Schizolobium parahyba and Pinus taeda. Wood Material Science \& Engineering, 11 (4): 209-216. https://doi.org/10.1080/17480272.2014.970574

24. Mechi, N.; Khiari, R.; Ammar, M.; Elaloui, E.; Belgacem, M. N., 2017: Preparation and application of Tunisian phosphogypsum as fillers in papermaking made from Prunus amygdalus and Tamarisk sp. Powder Technology, 312: 287-293.

https://doi.org/10.1016/j.powtec.2017.02.055

25. Mechi, N.; Khiari, R.; Elaloui, E.; Belgacem, M. N., 2016: Preparation of paper sheets from cellulosic fibres obtained from prunus amygdalus and Tamarisk sp. Cellulose Chemistry and Technology, 50 (7-8): 863-872.

26. Mojumder, P.; Mondal, S.; Mukhopadhya, S.; Sen, K., 2001: Chemical characterization of Khimp fibre (Leptadenia pyrotechnica). 60 (7): 675-677. https://hdl.handle.net/123456789/26532.

27. Moral, A.; Aguado, R.; Mutjé, P.; Tijero, A., 2016: Papermaking potential of Citrus sinensis trimmings using organosolv pulping, chlorine-free bleaching and refining. Journal of Cleaner Production, 112: 980-986. https://doi.org/10.1016/j.jclepro.2015.09.008

28. Nasser, R. A.; Hiziroglu, S.; Abdel-Aal, M. A.; Al-Mefarrej, H. A.; Shetta, N. D.; Aref, I. M., 2015: Measurement of some properties of pulp and paper made from date palm midribs and wheat straw by soda-AQ pulping process. Measurement, 62: 179-186.

https://doi.org/10.1016/j.measurement.2014.10.051

29. Pirralho, M.; Flores, D.; Sousa, V. B.; Quilhó, T.; Knapic, S.; Pereira, H., 2014: Evaluation on paper making potential of nine Eucalyptus species based on wood anatomical features. Industrial Crops and Products, 54: 327-334. https://doi.org/10.1016/j.indcrop.2014.01.040

30. Rudi, H.; Resalati, H.; Eshkiki, R. B.; Kermanian, H., 2016: Sunflower stalk neutral sulfite semi-chemical pulp: an alternative fiber source for production of fluting paper. Journal of Cleaner Production, 127: 562-566. https://doi.org/10.1016/j.jclepro.2016.04.049

31. Saeed, H. A.; Liu, Y.; Lucia, L. A.; Chen, H., 2017a: Evaluation of Sudanese Sorghum and Bagasse as a Pulp and Paper Feedstock. BioResources, 12 (3): 5212-5222. https://doi.org/10.15376/biores.12.3.5212-5222

32. Saeed, H. A.; Liu, Y.; Lucia, L. A.; Chen, H., 2017b: Sudanese Agro-residue as a Novel Furnish for Pulp and Paper Manufacturing. BioResources, 12 (2): 4166-4176. https://doi.org/10.15376/biores.12.2.4166-4176

33. Sarker, M.; Sutradhar, S.; Sarwar, A. G.; Uddin, M. N.; Chanda, S. C.; Jahan, M. S., 2017: Variation of chemical characteristics and pulpability of dhaincha (Sesbania bis- 
pinosa) on location. Journal of Bioresources and Bioproducts, 2 (1): 24-29.

34. Shakhes, J.; Marandi, M. A.; Zeinaly, F.; Saraian, A.; Saghafi, T., 2011a: Tobacco residuals as promising lignocellulosic materials for pulp and paper industry. BioResources, 6 (4): 4481-4493.

35. Shakhes, J.; Zeinaly, F.; Marandi, M. A.; Saghafi, T., 2011b: The effects of processing variables on the soda and soda-aq pulping of kenaf bast fiber. BioResources, 6 (4): 4626-4639.

36. Syed, N. F. N.; Zakaria, M. H.; Bujang, J. S., 2016: Fiber Characteristics and Papermaking of Seagrass Using Hand-beaten and Blended Pulp. BioResources, 11 (2): 5358-5380. https://doi.org/10.15376/biores.11.2.5358-5380

37. Tutuş, A.; Çiçekler, M.; Küçükbey, N., 2016: Pulp and Paper Production from Bitter Orange (Citrus aurantium L.) Woods with Soda-AQ Method. Kastamonu University Journal of Forestry Faculty, 16 (1): 14-18. https://doi.org/10.17475/kujff.29775

38. Tutus, A.; Comlekcioglu, N.; Karaman, S.; Alma, M. H., 2010: Chemical composition and fiber properties of Crambe orientalis and C. tataria. International Journal of Agriculture and Biology, 12 (2): 286-290. DOI: 09-435/SAT/2010/12-2-286-290.

39. Udoh, O. E.; Abu, N. E., 2016: Phenotypic variability in Nigerian castor (Ricinus communis L.) accessions. African Journal of Agricultural Research, 11 (42): 42224232. https://doi.org/10.5897/AJAR2016.10688

40. Vasconcelos, J. S.; de Almeida, D. H.; de Almeida, T. H.; Vasconcelos, J. C. S.; Christoforo, A. L.; Caraschi, J. C.; Lahr, F. A. R., 2014: Physical and Chemical Properties of
Fibrous Residues of Castor Bean Culture. International Journal of Materials Engineering, 4 (2): 75-78. https://doi.org/10.5923/j.ijme.20140402.05

41. Wise, L. E., 1946: Chlorite holocellulose, its fractionation and bearing on summative wood analysis and studies on the hemicelluloses. Paper Trade Journal, 122 (2): 35-43.

42. Wutisatwongkul, J.; Thavarungkul, N.; Tiansuwan, J.; Termsuksawad, P., 2016: Influence of Soda Pulping Variables on Properties of Pineapple (Ananas comosus Merr.) Leaf Pulp and Paper Studied by Face-Centered Composite Experimental Design. Advances in Materials Science and Engineering, 1-11.

https://doi.org/10.1155/2016/8915362

43. Yuan, Z.; Kapu, N. S.; Beatson, R.; Chang, X. F.; Martinez, D. M., 2016: Effect of alkaline pre-extraction of hemicelluloses and silica on kraft pulping of bamboo (Neosinocalamus affinis Keng). Industrial Crops and Products, 91: 66-75.

https://doi.org/10.1016/j.indcrop.2016.06.019

\section{Corresponding address:}

Professor, YU LIU

Dr. HAROON A. M. SAEED

Key Lab of Pulp and Paper Science and Technology Ministry of Education (Shandong Province)

Qilu University of Technology Jinan, 250353, Shandong, P.R. CHINA

e-mail: leoliuyu@163.com, haroonsaeed75@gmail.com 